\title{
Biochemistry and Psychology of Chess and Classical Physical Exercise: Concurring or Conflicting Evidence?
}

\section{Sighart Golf}

University of Giessen, Institute of Laboratory Medicine and Pathobiochemistry, Germany

*Corresponding author: Sighart Golf, University Medical School, University of Giessen, Institute of Laboratory Medicine and Pathobiochemistry, Rimbergstrasse 9, Biebertal, Germany 06409, Germany, Tel: 004964093066; E-mail: Sighart.Golf@klinchemie.med.uni-giessen.de

Rec date: Feb 25, 2015, Acc date: Mar 23, 2015, Pub date: Mar 25, 2015

Copyright: (c) 2015 Golf G. This is an open-access article distributed under the terms of the Creative Commons Attribution License, which permits unrestricted use, distribution, and reproduction in any medium, provided the original author and source are credited.

\begin{abstract}
Chess is a competitive sport in the classical meaning of the word. One of the most important factors for chess and sport competence is the accumulated time of training. In order to obtain a high level of competence, chess players and athletes alike must spend up 10 years of specific training.

In chess and classical sport energy needed for brain activity is first derived from glycogen stores in brain, muscles and liver and later from adipose tissue. Both, chess and classical sport rely on shared energy from glycogen and fat. When the brain needs additional energy, muscles and liver share energy with the brain. When muscles need additional energy, brain complies with the request of muscles. Energy expenditure, $\mathrm{O} 2$ uptake and $\mathrm{CO} 2$ production during chess games are similar to those obtained during a marathon. Mental and physical fatigue begin with similar metabolic states: deprivation of glycogen. During competitive chess, athletes must be in good physical condition.
\end{abstract}

Mental profiles of chess players and other athletes correlate with processes such as attention, conflict control, memory, motivation and recognition.

In chess there exists no gender-specific excellence; glycogen availability, however, is less developed in female chess players.

In chess and in classical sports, the brain, spinal cord, nerves and muscles cooperate in complete harmony. The brain commands everything: in chess the figures, in sport the cellular receptors (baro-, lactate-, gluco-, metabo-, chemo-, thermo-, respiratory-) "send" signals via eyes or metabolic changes to the brain. The brain then decides, what to do: in chess, the player moves a figure; in sports, muscles react according to demand.

Physical exercise or chess must be defined by a motor activity completely controlled by the central nervous system (CNS) in combination with a specific competence. In chess as well as in physical exercise, physical stress prepares brain to cognitive stimulation.

With respect to biochemical, physiological, neuronal and psychological aspects, chess is equals classical physical exercise and must be recognized as sport.

Keywords: Biochemistry; Psychology; Chess; Brain

\section{Introduction}

\section{Classical definition of sport}

The DOSB (national sports organization of Germany) expresses in its preamble: "The exercise of sport must have to its own end a specific motor activity depending on the kind of sport. This specific motor activity does not exist especially for mental games [1]".

Despite this exclusion of chess as sport, the German Chess Federation (DSB) has been accepted for more than 50 years as a member in the German Sports Federation (Deutscher Sportbund) and therefore also by the actual DOSB [2]. The membership in the DOSB entitles the DSB to receive financial support by the German Treasury.
In summary, the membership of the DSB in the DOSB is not clear as crystal, since a definite and widely accepted definition of "Sport" in Germany does not exist.

In spring 2014, the DOSB cancelled the financial support of the DSB with the argument, that chess as a mental game does not have as a purpose its own motor activity.

Common biochemical, physiological, neuronal and psychological fundamentals of chess and classical sport athletes are discussed to characterise chess as comparable with physical sport to secure the membership of the DSB in the DOSB. 


\section{CNS Control of Physical Exercise}

\section{How much of physical exercise is physical and how much mental?}

The is involved in every aspect of sport performance and is used to its fullest extent for maximal physical adaptation and performance.

To initiate skeletal muscle contractions voluntarily, action potentials arise in the motor cortex of the brain and are propagated down the spinal cord along upper motoneurons that synapse onto the lower motoneurons. Axons of the lower motoneurons leave the CNS and provide motor signals to particular groups of skeletal muscle fibers via neuromuscular junctions. Lower motoneurons and particular muscle fibers they innervate are called motor units [3]. The total number of fibers in man was never solidly estimated; On the basis of estimation of the muscle fiber numbers [4-8], an extrapolation with anthropometric data [9] results in circa $18 \times 10^{6}$ muscle fibers in man.

In addition to inducing contractions, CNS monitors the performance of muscles: Sensory receptors located in muscles, tendons, and joints in conjunction with afferent neurons, i.e. barosensors, chemosensors, metabosensors, thermosensors, respiratory sensors [10] send feedback information in form of action potentials to the CNS concerning muscle length, limb position, rate of movement, and contraction tension. This permits stimulation of maximally $18 \times 10^{6}$ muscle fibres to be continuously and appropriately modified so that the actual performance matches the intended performance.

An interruption of this afferent sensory pathway, for example by a spinal cord injury, will result in a complete loss of kinaesthetic sense, i.e., a complete loss of muscle functionality.

\section{Psychology of Physical Exercise}

Lately, a growing interest in cognitive sport psychology and systematic study of mental processes in sports performers has been observed [11]. Mental processes of cognition usually expected in chess players have been studied in all sport specialities [12-14]. The mental processes include intelligence [15], expertise [16,17], perception [18], memory [19], anticipation [20], attention [21], mental imaging [11], judgement and decision making [22]. The most important factor for acquiring athletic skill in any sport discipline is the accumulated duration of special training [23].

\section{Athletic Skill}

Athletic skill is present, when players have a learnt ability to select and perform the correct technique as determined by demands of the situation. Decision making is the fundamental element of skill. When compared with less-skilled competitors, adult athletic experts are better at anticipating opponents' intentions based on partial information or advance cues, and can more consistently pick up minimal essential information needed for successful anticipation. Experts typically exhibit more effective visual search strategies and are faster and more accurate at recognizing and recalling typical patterns of play from memory [12].

\section{Decision Making}

Decision making depends on a step-by-step pattern from perception, evaluation, and selection to execution [24]. Knowledge bases and cognitive strategies underlying effective performance develop gradually as a result of extensive task-specific practice. Only experienced athletes are able to discriminate task-relevant from taskirrelevant information [14] and encode a greater number of alternative strategies faster. Experts dismiss many events as being highly improbable and attach a hierarchy of probabilities to remaining possibilities. They pick up task-relevant information to predict the best options available to the athlete.

\section{Anticipation and Prediction}

When compared with their less-skilled counterparts, adult experts are better at anticipating opponents intentions based on partial information or advance cues, and can more consistently pick up the minimal essential information needed for successful anticipation. Experts typically exhibit more effective visual search strategies and are faster and more accurate at recognizing and recalling typical patterns of play from memory $[14,25]$.

\section{Memory}

The ability to recall athletes ' positions from memory in offence and defence in a team play is dependent on memory [14].

The ability of elite players to recall both structured and unstructured patterns of play increases with age. Experienced adults demonstrate less error in recalling key player positions from typical patterns of play when compared to inexperienced players [26].

\section{Mental Imagery}

Action execution, imagery and observation are functionally equivalent for the brain [27]. They are based on the same actionspecific and effector-specific motor representations [28]. Imagining the performance of a skill with no related overt actions is the most prevalent form of mental rehearsal used in athletics. World-class athletes and coaches use imagery thoroughly.

Imagery improves athletic performance when used alone and in conjunction with other cognitive techniques to improve learning and acquisition of motor and patterns of movement. Mental imagery also enhances the transfer of an acquired skill from practice to performance. It is most effective when combined with physical practice [29].

\section{Conclusions}

Expert performances and differences between experts and nonexperts in physical sport depend on experience [30]. The skilled performers' superiority over the less skilled and novices is based on cognitive skills essential for effective anticipation and decision making processes. These skills include memory, anticipation, prediction, advance visual cue utilization, pattern recall and recognition, visual search behaviour and knowledge of situational probabilities, which together are referred to as "game intelligence" [31].

\section{Significance of Motor and Mental Activity for the Definition of Sport}

All competitive athletes - whether in football, dart or chess - must meet two requirements to compete successfully: First, they need a 
specific, long learned mental expertise in football as a team-sport, dart and chess as individual sport [32].

Secondly, all competitors need muscles for the physical part of the exercise.

When the corresponding mental expertise is available, the specific muscle fibres are activated according to the commands of the brain.

The muscle in itself is a "dumb" organ. It cannot work on its own, it cannot interpret metabolic signals coming from its receptors or events, it does not know, when to accelerate or to slow down. A muscle without control by the CNS is a muscle as bad off as after a spinal cord injury with a complete interruption of signalling from the CNS.

\section{Balance of Energy Resources of Man during Mental and Physical Exercise}

Three principal energy resources are available to humans for energy-dependent processes such as physical and mental stress situations: Creatine-phosphate and ATP present in cells, glycogen derived from blood glucose present in cells of muscle, liver and brain and some other organs [33], and fatty acids from adipose tissue.

The most important energy resources for daily occurring tasks as well as for mental and physical exercise is glycogen in brain [34], liver and muscle [35].

In man, glucose from glycogen in cells of liver, muscle and brain is available for glycolysis on demand within seconds [36]. A decrease of glucose in the blood by physical or mental stress leads to hydrolysis of glycogen delivering additional glucose [37]. When glucose in blood increases by nutrition, insulin enters the brain [38], liver and muscle to start glycogen-synthesis. During routine tasks of the day and In times when humans rely on anaerobic glycolysis for rapidly available fuel during short periods of intense mental and physical exertion, or when oxygen is limited [39], muscle and brain cells rely on anaerobic glycolysis. Anaerobic glycolysis produces energy 100times faster than aerobic respiration [39-42]. When glucose stores in muscle and brain are lowered, energy is gained from glycogen in liver and B-oxidation of fatty acids in adipose tissue [40]. When energy is needed for continuously enduring physical exercise, even brain glucose is made available for muscles [43].

Spirometric analysis is applied in traditional sport, medical diagnosis and therapy [44] and in chess tournaments, where the respiratory exchange ratio is raised $(>0.89)$ at the start of a chess competition and decreases during the game to 0.75 , indicating that energy expenditure switched from carbohydrate to lipid oxidation [45]. The changes in substrate oxidation are caused by high cognitive demands and bring new insight into adaptations to mental strain.

\section{Energy Expenditure of Brain and CNS for Mental and Physical Exercise}

In chess as well as physical exercise, a series of metabolic, physicochemical and physical signals are on the way in order to move a hand. First of all, the activation pattern of motor cortex neurons does two things--it specifies for the peripheral motor system both what to do and how to do it [46]. The signals move from the brain cortex through the spinal cord to nerves to muscle cells.

There exist not only one signal during a physical movement of an extremity, but many more. When one biceps muscle is in motion during the execution of a chess move, then ca. 250000 muscle cells receive signals [4]. When half the 640 muscles of man are in motion during a marathon, then signals must reach 10 million muscle fibers. Signals are sent back from every muscle cell in motion to the brain, coming from baro-, lactate-, gluco-, metabo-, chemo-, thermo-, respiratory-, etc-receptors. The brain evaluates the signals and if needed, sends new signals, and so on and so on.... during every second of the whole marathon, or chess game!

The brain is an expensive tissue [47]. Grey brain matter needs double the energy of the rest of the brain [48] because of the high signalling-related energy demand in grey matter [49], for which $75 \%$ of the energy is necessary. With this level of energy expenditure, brain uses more energy than the human leg muscle during a marathon [50].

\section{Physical Exercise during Competitive and Professional Chess}

The laws of chess have been defined by the FIDE and were adopted at the 79th FIDE Congress at Dresden (Germany), November 2008 and came into force in July 2009 [51]. The FIDE specified, that during official chess competitions chess must be carried out using a physical chess board and 32 figures, which must be moved by the players. Additionally chess players must activate a special chess-clock after moving a chess piece and must personally write down the specified chess notation.

The involvement of physical exercise for chess tournaments is very evident. A professional chess expertise is obtained only after numerous hours of training. Gobet estimated [52], that after 50000 hours of training a very good chess player remembers at least 300000 chess positions so that he is able to recognize and then to compare and to act [53]. Training time is one of the most effective prognostic factor for achieving very good chess expertise [54] and not intelligence [54]. At least 5000-10000 hours of chess training time during the first ten years must be invested to reach professional chess competence $[55,56]$, and this as early in life as possible [57].

In order to remember 50000-300000 chess positions, one has to assemble chess figures on the board at least two or three times per position. In summary the player positions at least 2-3 million chess figures in those ten years.

Chess games might last up to 7 hours (own experience). The actual chess Bundesliga (first division) of Germany for example carried out the last 3 games on three consecutive days (April 2014).

A very exciting form of chess is "blitz" chess, where the players have only 5 minutes time to complete the whole game, which might last for more than 50 moves. Many championships are carried out in blitz chess including world-championships. If a blitz chess tournament with 20 players is carried out during one evening, each player must move at least 1000 chess figures in addition to 1000 activation of the chess clock by finger pressure.

The first study of autonomic excitability and metabolic load of high-class chess players during an 18 day tournament was carried out in 1980 [58]. It was concluded, that the autonomic excitability and circulatory parameters (heart-rate, HR) during the competition of the chess players were completely comparable to other sportsmen of similar athletic performance. Later studies confirmed these observations on human circulatory parameters [59-61]. 
An increase in $\mathrm{HR}$ is the physiologic response of the human body to a change in physical or mental balance. In chess, the change of HR is connected to physical exercise and to specific events during the chess game and it reflects reactions, such as a blunder made by the opponent, by fluctuations subsequent to the move, by a sacrifice, a difficult defence, or even by the winning move $[58,60]$. These observations demonstrate that fluctuations of HR constitute a broad marker integrating a series of physical and mental variables.

Stress can be defined as the brain's response to any demand. Mental stress during physical exercise is a common experience for involved athletes, since it is intrinsically linked with an additional increase in HR. Mental stresses include normally occurring events, for example anxiety, anticipation and unexpected events $[62,63]$, and cognitive exercises $[62,64,65]$.

\section{Physical Exercise to Improve Chess Expertise}

HR measured during chess tournaments may include peaks in excess of $220 / \mathrm{min}$ with a single maximum of $223 / \mathrm{min}$ [59]. Not surprisingly, the peak HR is reached in the time pressure phase towards the end of the sixth hour of play [58]. The player's adrenaline level can reach eight times its normal value [59]. This sympathoadrenal response in chessplayers during chess-competitions closely resembles that during strenuous physical exercise [66]. Players experiencing $\mathrm{HR}$ in excess of $200 / \mathrm{min}$ and big increases in catecholamines are prone to make simple mistakes caused by extreme physical pressure. Players who are in good physical condition are able to cope better, having much lower HR, hardly any catecholamine increase and make fewer errors. Therefore chess expertise alone is insufficient to compete in chess tournaments. Chess players additionally need a corresponding physical fitness in order to endure exhausting chess plays.

The benefits of regular, but moderate physical exercise are wellestablished. The American College of Sports Medicine [67] states that physical exercise improves stress responses such as HR, blood pressure and release of stress hormones to physical and mental stress situations.

Exercise training is effective in improving physical skills [68], and it is also effective in reducing reactivity to psychological stress in terms of cognitive and somatic anxiety, behavioural anxiety during the anticipation of the stressor, and speed of HR recovery after stress.

Physical exercise and mental performance are closely and structurally related in natural conditions. Cognitive processes like trial and error [69] direct behavioural adjustments and sometimes result in behavioural novelties which allow the organism to cope with environmental pressures. Under long-lasting environmental changes, these behavioural adaptations can become hereditary [70]. There exist some brain-structures which are under genetic control and might evolve under selective pressures. These include brain size, the ratio of various brain structures to the whole brain, number and density of neurons in various parts of the brain and variations of neuronal circuitry.

Based on evidence from human and animal studies, there exists a genetic correlation between acute physical aerobic exercise and improvement of cognitive function and deceleration of deterioration of mental processes [71]. Fitness training with laboratory animals selectively enhances angiogenesis, synaptogenesis, neurogenesis in the hippocampus [72] and upregulates a number of neurotrophic factors. Aerobic exercise has significant positive effects on a large range of other cognitive functions including auditory and visual attention, motor control, spatial cognition and cognitive speed and spatial memory [73]. The largest positive effects were observed for executive control processes such as cognition, planning, scheduling, memory and multitasking [74].

Physical exercise facilitates neuroplasticity and enhances the capacity to respond to new demands with behavioural adaptations. Studies suggested that combining physical and cognitive training might result in a mutual enhancement of both interventions. Moreover, maintenance of neurocognitive benefits induced by physical exercise may be secured by increases in cardiovascular fitness [75]. Physical exercise may also prepare the brain to respond to cognitive stimulation [76]. A cognitive training then induces neuronal changes in specific networks associated with the trained skill.

Especially chess players will benefit from these resources, since the image obtained by a mental decision process is an exact match to that obtained by moving chess figures on the chess board. Consequently, chess training with computers would largely eliminate physical exercise and therefore preparation of the brain to cognitive stimulation.

\section{Physiology and Biochemistry of Chess}

\section{Brain energy resources during chess}

Brain energy sources are glycogen located in brain, liver and muscle and some other organs, and from adipose tissue located outside of the brain.

Glycogen stores in brain are small compared to liver and, especially muscles. Brain glycogen turns over rapidly [77] and contributes significantly to normal brain energy metabolism [78]. Glycogen is located almost entirely in astrocytes [79], the multitudinous cells in brain, which are distributed throughout the brain and mostly concentrated in fiber bundles and white matter $[80,81]$.

\section{Energy expenditure during chess}

Neural information-processing of information is metabolically expensive. Although the human brain contributes only $2 \%$ to the body's weight, it accounts for $20 \%$ of its resting energy metabolism [82].

Most of the brain's energy is used for signalling processes, particularly $\mathrm{Na}+$ transport. The brain has small energy reserves, and the safety margin between energy that can be generated and energy required for maximum activity is small. The supply of energy from glycogen limits the activity of neurons [83].

Since anaerobic energy from glycogen is obtained 100 times faster than aerobic energy, the brain is able to function in competitive chess at maximal performance only through anaerobic glycolysis. When lactate coming from anaerobic glycolysis is exhausted, the brain "talks" to adipose tissue and energy coming from ß-oxidationof fatty acids will be available [45].

\section{Mental and Physical Fatigue}

Fatigue is defined as the difficulty initiating or sustaining voluntary activities. Fatigue is considered a safety mechanism to prevent changes in metabolism that could result in irreversible damage to muscles and brain. Fatigue decreases the efficiency in performing tasks. Mental 
fatigue especially represents a potential failure to complete mental tasks $[84,85]$.

Some metabolic causes of fatigue are decreases in creatinephosphate in muscles, depletion of glycogen stores in brain, liver and muscle, hypoglycaemia in the body [86].

Mental fatigue is characterized by a slower cognitive performances and an impaired selective attention, due to reduced availability of fast energy from anaerobic glycolysis. The high level of mental effort introduces a greater level of impaired conflict control, which is of elemental importance for chess players confronted with continuously developing and changing conflicts throughout the game. Selective attention processes activate the anterior cingulated cortex (ACC) and the dorsolateral prefrontal cortex (DLPFC) [87] where structures of chess cognition are located [88]. General fatigue is associated with ACC and DLPFC [89,90]. Fatigue will therefore cause deteriorated cognitive performances through impaired functions in these brain regions with reduced attention and conflict control $[86,91]$.

\section{Chess Expertise}

\section{Mental profile of professional chess players}

Expertise in chess enables the player to perform as an expert in a cognitive domain [92,93], which taps many cognitive processes [94], that are associated with intelligence, mental speed, spatial abilities, working memory [95-98], anticipation and transfer [99,100], perception [101,102], motivation [103] attention [104] and recognition [105].

\section{Chess practice}

Serious study alone is the strongest predictor of chess skill [54]. Chess players at the highest skill level expended about 5000 hours on serious study alone during their first decade of serious chess play.

A strong correlation exists between the number of hours, chess players have dedicated to chess and their current rating [52]. Unrated players reported more than 8000; rated but untitled players reported close to 12000; Fidemasters reported almost 20000 and the International Masters reported 28000 hours of dedication to chess.

\section{Decision}

Since expert chess players search less on the chess board than lower grade chess players, yet still manage to find strong chess moves, research attention has shifted from investigating search processes to the role of pattern recognition processes in move selection. Skilled players use their knowledge of chess configurations to recognize plausible moves for limited searching [106].

This result suggests that better players have a larger visual field on the chess board from which they can extract chess relationships and the experts are more likely to concentrate on relevant squares on the board [107].

In summary, experts rely on a rich network of chess patterns stored in long time memory (LTM) structures to give them a larger visual span when encoding chess positions more quickly than non-experts [108]. Within the first second of exposure to a new position, experts examine salient squares and simultaneously extract chess relationships critical to choosing good moves.

\section{Memory [109]}

The template theory [97] states, that human cognition comprises three main modules: a visuo-spatial imagery system, a short-term memory (STM), where information is briefly stored, and LTM, which consists both of structures indexing the information and the information itself. LTM consists of declarative knowledge (the 'what'), encoded as schemata, and of procedural knowledge (the 'how'), encoded as productions. Perceptual and conceptual information that can be used as units are called chunks, and constitute the building blocks out of which knowledge is constructed. These considerations are strengthened by the observation [96], that expert chessplayers find only a few chunks in random chess positions.

They encode chess information far more quickly and accurately than non-experts and it is estimated, that it takes about ten seconds to learn a new chunk in the LTM [110].

Skill does not reside in differences in STM capacity or encoding speed, but in the number of complex units such as chess positions held in LTM $[111,112]$. These complex units give access to information coming from the LTM such as what move to play, what plan to follow, and what evaluation to give to the position.

Based upon computer simulations with the computer program MAPP, it was calculated, that one needed to acquire from 10,000 to 100,000 patterns to reach master level in chess [110]. Computer simulations with the computer program CHREST show that at least 300,000 complex units are required to reach grandmaster level [52].

\section{Intelligence}

\section{Does chess need intelligence? [55]}

In contrast to contrary claims [102], world-class chess players have no exceptional intellectual abilities [113]. This finding has been confirmed several times [55,114].

Recently, the role of intelligence in chess was extended and specialized $[115,116]$. Six variables were identified:

- The age entering the chess club

- The number of tournament games

- The emotion expression control

- the numerical intelligence

- The actual age and finally

- The chess-related performance motivation

which account for ca. $60 \%$ of the variability of the ELO-rankings (derived by the ELO-formular used to calculate the relative skill of chess players from results achieved in official chess tournaments), showing that playing strength in chess can be best predicted by domain-specific practice.

It is concluded, that expert chess players display significantly higher selective intelligence than controls and their playing strength is related to the selective intelligence level. In addition, by using the extended expert-novice paradigm (comparing experts with novices of different intelligence levels) it has been found that both, expertise and intelligence have an impact on the performance in expertise-related tasks [115]. It is presumed, that expertise in chess play does not stand in isolation from selective intelligence $[116,117]$. 
Citation: Golf S (2015) Biochemistry and Psychology of Chess and Classical Physical Exercise: Concurring or Conflicting Evidence?. J Sports

Page 6 of 10

\section{Chess and Gender}

There exists no gender specific intellectual performance in humans for chess playing despite several different opinions [102,118-124]. Since both women and men use glycogen from brain liver and muscle for fast energy during physical stress and during chess playing, mental fatigue occurs earlier in women $[125,126]$, because their body glycogen content is lower if compared to men due to hormonal conditions [127-131] and chess demand for fast energy for women is equal to men. This would indeed lower speed of conflict control at an earlier time point for women during a chess game.

Nevertheless, the regional, national, continental, World and Olympic Championships in chess are open for men and women and are often carried out with both men and women In addition, special women-leagues exist in many countries, mostly with the aim to establish and support regular chess playing by women.

Definition of Sport

Sport is a regulated form of physical, neuromuscular and mental activity organized as a contest between two or more participants for the purpose of determining a winner by fair and ethical means $[2,132]$.

The criteria by which the DOSB limits its acceptance of membership (see Introduction) cannot be applied for this purpose [133]. A specific motor activity is by no means an end in itself, but always has been beyond that means for reaching higher-ranking purposes. During the evolution of mankind, physical activity was absolutely necessary for survival. In modern times, physical activity in the form of sport is carried out for countless purposes including amusement, competition, entertainment, health, money, socialisation and so on.

Therefore this definition of sport is suggested: (Table 1)

1. Organized conductance of sport

2. Rules

3. Temporally and locally limited in scale

4. Use of technical tools

5. Physical, mental and neural activity

6. Conservation and promotion of health

7. Usefulness for education

8. Gratification of human play instinct

9. Game

10. Body and mental training

11. Teamsport

12. Availability for professional sport

13. Competition

14. Orientation toward maximum performance

\begin{tabular}{|c|c|c|c|c|}
\hline Administration and Organisation & Sport (Soccer) & Chess & References & \\
\hline & & & Sport & Chess \\
\hline Member of DOSB & + & + & [1] & [1] \\
\hline Organized conductance of sport & + & + & [1] & [1] \\
\hline Rules & + & + & [1] & [1] \\
\hline Temporally and locally limited scale & + & + & [2] & [2] \\
\hline Use of technical tools & + & + & [2] & [2] \\
\hline \multicolumn{5}{|l|}{ Body and mind } \\
\hline Physical activity & + & + & [1] & [51] \\
\hline Mental activity & + & + & [1] & [1] \\
\hline Conservation and promotion of health & + & + & [1] & [1] \\
\hline Useful for education & + & + & [1] & [1] \\
\hline Gratification of human play instinct & + & + & [1] & [1] \\
\hline Game & + & + & [1] & [1] \\
\hline Physical and mental training & + & + & [1] & [1] \\
\hline Teamsport & + & + & [1] & [1] \\
\hline \multicolumn{5}{|l|}{ Professionalism } \\
\hline Availability for professional sport & + & + & [2] & [2] \\
\hline Competition & + & + & [1] & [51] \\
\hline
\end{tabular}


Citation: Golf S (2015) Biochemistry and Psychology of Chess and Classical Physical Exercise: Concurring or Conflicting Evidence?. J Sports Med Doping Stud 5: 158. doi:10.4172/2161-0673.1000158

Page 7 of 10

\begin{tabular}{|c|c|c|c|c|}
\hline Orientation toward maximum performance & + & + & [1] & [1] \\
\hline \multicolumn{5}{|l|}{ Energy } \\
\hline Glycogen from brain & + & + & [34] & [34] \\
\hline Glycogen from Liver & + & + & [35] & [35] \\
\hline Glycogen from muscle & + & + & [35] & [35] \\
\hline Adipose tissue & + & + & [40] & {$[40]$} \\
\hline \multicolumn{5}{|l|}{ Brain, nerves } \\
\hline Control of activity & + & + & [3] & [3] \\
\hline Signaling by brain, spinal cord and nerves & + & + & [3] & [3] \\
\hline \multicolumn{5}{|l|}{ Cardio-respiratory system } \\
\hline $\mathrm{HR}$ & + & + & [67] & [58] \\
\hline Blood pressure & + & + & [67] & [58] \\
\hline VO2 & + & + & [44] & [58] \\
\hline Respiratory quotient & + & + & [44] & [45] \\
\hline \multicolumn{5}{|l|}{ Hormones } \\
\hline Catecholamines & + & + & [66] & [58] \\
\hline \multicolumn{5}{|l|}{ Mental Performance } \\
\hline Anticipation & + & + & [20] & [99] \\
\hline Attention & + & + & [21] & [87] \\
\hline Conflict control & + & + & [22] & [106] \\
\hline Decision & + & + & [22] & [106] \\
\hline Expertise & + & + & [16] & [116] \\
\hline Images & + & + & [11] & [112] \\
\hline Intelligence & + & + & [15] & [115] \\
\hline Memory & + & + & [14] & [101] \\
\hline Motivation & + & + & [15] & [103] \\
\hline Perception & + & + & [18] & [101] \\
\hline Prediction & + & + & [25] & [30] \\
\hline Recognition & + & + & [12] & [30] \\
\hline Training time & + & + & [23] & [54] \\
\hline
\end{tabular}

Table 1: Summary of concordance between chess and classical sport.

\section{Conclusion}

Competitive chess is equal to classical sport with regard to physical, mental and neuronal activity, effects on conservation and promotion of mental and physical health as well as on professional, educational and recreational human needs.

During chess and physical sport, brain commands every muscle action, which moves a finger, a leg or arm, etc. The expert athlete has gained a specific mental and more or less a physical skill by a specific training period of many years. In brain, prior to the initiation of any muscle contraction, a series of neuronal signals occur as a consequence of corresponding signals arriving from muscle cells in the brain and which are expressed as mental procedures such as anticipation, prediction, conflict control, and finally decision. The decision is supported by a correspondingly specific memory including mental images. As a result of the cooperative expert work of brain and muscle, 
a deciphered physical movement results such as a specific movement of a chess figure on the chess board or of a thrown javelin.

\section{Acknowledgement}

The author thanks Dr. Ernst Ulrik Lettau, anglicist, Ernst Bedau, formerly counsellor of the German Chess Federation (DSB) and Dan Peter Poetke, referee for women-chess in the DSB for assistance during the preparation of the manuscript

\section{References}

1. http://www.dosb.de/en/organisa-tion/philosophie/sportdefinition.

2. Holzke F (2001) Der Begriff Sport im deutschen und im europäischen Recht. Universität zu Köln.

3. Glaser RM, Janssen TW, Suryaprasad AG, Gupta SC, Mathews T (1996) The physiology of exercise. Physical fitness: A guide for individuals with spinal cord injury 14: 3 .

4. Klein CS, Marsh GD, Petrella RJ, Rice CL (2003) Muscle fiber number in the biceps brachii muscle of young and old men. Muscle Nerve 28: 62-68.

5. MacDougall JD, Sale DG, Alway SE, Sutton JR (1984) Muscle fiber number in biceps brachii in bodybuilders and control subjects. J Appl Physiol Respir Environ Exerc Physiol 57: 1399-1403.

6. McCall GE, Byrnes WC, Dickinson AL, Fleck SJ (1998) Sample size required for the accurate determination of fiber area and capillarity of human skeletal muscle. Can J Appl Physiol 23: 594-599.

7. Etemadi AA, Hosseini F (1968) Frequency and size of muscle fibers in athletic body build. Anat Rec 162: 269-273.

8. Barin-baum DE (1963) [Concerning the number of fibers in the human biceps brachii muscle with regard to the type of body build]. Acta Anat (Basel) 55: 224-254.

9. Daffner F (1902) Das Wachstum des Menschen: anthropologische Studie. W Engelmann 1902: 495.

10. American College of Sports Medicine, Farrell PA, Joyner MJ, Caiozzo VJ (2006) ACSM's advanced exercise physiology. Lippincott Williams \& Wilkins 143: 197-245.

11. Moran A (2009) Cognitive psychology in sport: Progress and prospects. Psychology of Sport and Exercise 10: 420-426.

12. Ali A (2011) Measuring soccer skill performance: a review. Scand J Med Sci Sports 21: 170-183.

13. Orlick T, Partington J (1988) Mental links to excellence. The sport psychologist 2: 105-130

14. Paul W, Mark WA (2003) "Perceptual and cognitive skill development in soccer: The multidimensional nature of expert performance. J Sport Exerc Psychol 25: 93.

15. Konter E (2010) Nonverbal intelligence of soccer players according to their level of play. Procedia-Social and Behavioral Sciences 2: 1114-1120.

16. Balser NH (2014) Expertise bei der Antizipation sportmotorischer Handlungseffekte: neuronale Aktivierung motorik-relevanter Gehirnareale. Justus-Liebig-Universität Gießen.

17. Müller S, Abernethy B, Farrow D (2006) How do world-class cricket batsmen anticipate a bowler's intention? Q J Exp Psychol (Hove) 59: 2162-2186.

18. Memmert D, Furley P (2007) "I spy with my little eye!": breadth of attention, inattentional blindness, and tactical decision making in team sports. J Sport Exerc Psychol 29: 365-381.

19. Dijkstra K, MacMahon C, Misirlisoy M (2008) The effects of golf expertise and presentation modality on memory for golf and everyday items. Acta Psychol (Amst) 128: 298-303.

20. Aglioti SM, Cesari P, Romani M, Urgesi C (2008) Action anticipation and motor resonance in elite basketball players. Nat Neurosci 11: 1109-1116.

21. Milton J, Solodkin A, Hlustík P, Small SL (2007) The mind of expert motor performance is cool and focused. Neuroimage 35: 804-813.
22. Bar-Eli M, Raab M (2006) Judgment and decision making in sport and exercise: Rediscovery and new visions. Psychol Sport Exerc 7: 6.

23. Helsen WF, Hodges NJ, Van Winckel J, Starkes JL (2000) The roles of talent, physical precocity and practice in the development of soccer expertise. J Sports Sci 18: 727-736.

24. Zentgraf K, Green N, Munzert J, Schack T, Tenenbaum G, et al. (2009) How are actions physically implemented? Prog Brain Res 174: 303-318.

25. Williams AM (2000) Perceptual skill in soccer: implications for talent identification and development. J Sports Sci 18: 737-750.

26. Gucciardi DF, Jackson B, Hanton S, Reid M (2015) Motivational correlates of mentally tough behaviours in tennis. J Sci Med Sport 18: 67-71.

27. Jeannerod M (2001) Neural simulation of action: a unifying mechanism for motor cognition. Neuroimage 14: S103-109.

28. Lorey B, Naumann T, Pilgramm S, Petermann C, Bischoff M, et al. (2013) How equivalent are the action execution, imagery, and observation of intransitive movements? Revisiting the concept of somatotopy during action simulation. Brain Cogn 81: 139-150.

29. Jones L, Stuth G (1997) The uses of mental imagery in athletics: An overview. Appl Prev Psychol 6: 101-115.

30. Ericsson KA, Charness N, Feltovich PJ, Hoffman RR (2006) The Cambridge handbook of expertise and expert performance. Cambridge University Press.

31. Stratton G (2004) Youth soccer: From science to performance. Psychology Press.

32. Ericsso KA, Krampe RT, Tesch-Römer C (1993) The role of deliberate practice in the acquisition of expert performance. Psychological review 100: 363.

33. Jacob RH, Pethick DW (2002) Comparative changes in glycogen concentrations after exercise in muscle, liver, kidney, skin and duodenum of sheep. Asia Pac J Clin Nutr 11: S274-S274.

34. Hutchins DA, Rogers KJ (1970) Physiological and drug-induced changes in the glycogen content of mouse brain. Br J Pharmacol 39: 9-25.

35. Campbell NA, Williamson B, Heyden RJ (2003) Biology: exploring life. Recording for the Blind \& Dyslexic.

36. Hers HG (1976) The control of glycogen metabolism in the liver. Annu Rev Biochem 45: 167-189.

37. Halse R, Bonavaud SM, Armstrong JL, McCormack JG, Yeaman SJ (2001) Control of glycogen synthesis by glucose, glycogen, and insulin in cultured human muscle cells. Diabetes 50: 720-726.

38. Duarte AI, Moreira PI, Oliveira CR (2012) Insulin in central nervous system: more than just a peripheral hormone. J Aging Res 2012: 384017.

39. Bustamante E, Pedersen PL (1977) High aerobic glycolysis of rat hepatoma cells in culture: role of mitochondrial hexokinase. Proc Natl Acad Sci U S A 74: 3735-3739.

40. Hultman E, Harris RC (1988) Principles of Exercise Biochemistry.

41. Delmastro-Greenwood MM, Piganelli JD (2013) Changing the energy of an immune response. Am J Clin Exp Immunol 2: 30-54.

42. Pfeiffer T, Schuster S, Bonhoeffer S (2001) Cooperation and competition in the evolution of ATP-producing pathways. Science 292: 504-507.

43. Kemppainen J, Aalto $\mathrm{S}$, Fujimoto $\mathrm{T}$, Kalliokoski KK, Långsjö $\mathrm{J}$, et al. (2005) High intensity exercise decreases global brain glucose uptake in humans. J Physiol 568: 323-332.

44. O'Connor FG, Kunar MT, Deuster PA (2009) Exercise Physiology for Graded Exercise Testing: A Primer for the Primary Care Clinician. Exercise Stress Testing for Primary Care and Sports Medicine 3-22.

45. Troubat N, Fargeas-Gluck MA, Tulppo M, Dugué B (2009) The stress of chess players as a model to study the effects of psychological stimuli on physiological responses: an example of substrate oxidation and heart rate variability in man. Eur J Appl Physiol 105: 343-349.

46. Ajemian R, Bullock D, Grossberg S (2000) Kinematic coordinates in which motor cortical cells encode movement direction. J Neurophysiol 84: 2191-2203. 
47. Aiello LC, Wheeler P (1995) The expensive-tissue hypothesis: the brain and the digestive system in human and primate evolution. Current anthropology 36: 199-221.

48. Attwell D, Laughlin SB (2001) An energy budget for signaling in the grey matter of the brain. J Cereb Blood Flow Metab 21: 1133-1145.

49. Clarke DD, Sokoloff L (1999) Circulation and energy metabolism of the brain. Basic neurochemistry: molecular, cellular and medical aspects. 6: 637-669.

50. Hochachka PW (1994) Muscles as molecular and metabolic machines.

51. http://www.fide.com/component/handbook/?id=171\&view=article

52. Gobet F, Charness N (2006) Chess and games. The Cambridge handbook of expert performance. Cambridge University Press, New York 41-67.

53. Calderwood R, Klein GA, Crandall BW (1988) Time pressure, skill, and move quality in chess. Am J Psychol 481-493.

54. Charness N, Tuffiash M, Krampe R, Reingold E, Vasyukova E (2005) The role of deliberate practice in chess expertise. Appl Cognit Psychol 19: 151-165.

55. Bilalic M, McLeod P, Gobet F (2007) Does chess need intelligence? - A study with young chess players. Intelligence 35: 457-470.

56. Bilalic M, McLeod P, Gobet F (2007) Personality profiles of young chess players. Personality and Individual Differences 42: 901-910.

57. Gobet F, Campitelli G (2007) The role of domain-specific practice, handedness, and starting age in chess. Dev Psychol 43: 159-172.

58. Pfleger H, Stocker K, Pabst H, Haralambie G (1980) [Sports medica examination of top class chess players (author's transl)]. MMW Munch Med Wochenschr 122: 1041-1044.

59. Hollinsky C, Maresch G, Hiller M, Kohlberger P, Bieglmayer C (1997) Beeinflußt körperliche Fitneßdie Leistungsfähigkeit von Ranglistenschachspielern. Ö J Sportmed 27: 51-59.

60. Leone MJ, Petroni A, Fernandez Slezak D, Sigman M (2012) The tell-tale heart: heart rate fluctuations index objective and subjective events during a game of chess. Front Hum Neurosci 6: 273.

61. Pfleger H, Metak G (1981) Sportmedizinische Untersuchungen an Schachspielern beim Schachmedizin-Turnier. Herausgeber Deutscher Sportbund - Bundesausschuß Leistungssport 1981: 1-75.

62. Acevedo EO, Webb HE, Weldy ML, Fabianke EC, Orndorff GR, et al. (2006) Cardiorespiratory responses of Hi Fit and Low Fit subjects to mental challenge during exercise. Int J Sports Med 27: 1013-1022.

63. Baden DA, McLean TL, Tucker R, Noakes TD, St Clair Gibson A (2005) Effect of anticipation during unknown or unexpected exercise duration on rating of perceived exertion, affect, and physiological function. Br J Sports Med 39: 742-746.

64. François B, Cahen R, Gravejat MF, Estrade M (1984) Do beta blockers prevent pressor responses to mental stress and physical exercise? Eur Heart J 5: 348-353.

65. Webb HE, Weldy ML, Fabianke-Kadue EC, Orndorff GR, Kamimori GH et al. (2008) Psychological stress during exercise: cardiorespiratory and hormonal responses. Eur J Appl Physiol 104: 973-981.

66. Holmqvist N, Secher NH, Sander-Jensen K, Knigge U, Warberg J, et al. (1986) Sympathoadrenal and parasympathetic responses to exercise. Sports Sci 4: 123-128.

67. American College of Sports Medicine (2013) ACSM's guidelines for exercise testing and prescription. Lippincott Williams \& Wilkins.

68. Calvo MG, Szabo A, Capafons J (1996) Anxiety and heart rate under psychological stress: The effects of exercise-training. Anxiety Stress Coping 9: 321-337.

69. Beer CG (1995) Trial and error in the evolution of cognition. Behav Processes 35: 215-224.

70. Lassalle JM (1995) Neurogenetic basis of cognition: Facts and hypotheses. Behav Processes 35: 5-18.

71. Stuer S (2010) The Effects of Physical Exercise on Cognition.

72. Hillman CH, Erickson KI, Kramer AF (2008) Be smart, exercise your heart: exercise effects on brain and cognition. Nat Rev Neurosci 9: 58-65.
73. Angevaren M, Aufdemkampe G, Verhaar HJ, Aleman A, Vanhees L (2008) Physical activity and enhanced fitness to improve cognitive function in older people without known cognitive impairment. Cochrane Database Syst Rev 16: CD005381.

74. Kramer AF, Erickson KI, Colcombe SJ (2006) Exercise, cognition, and the aging brain. J Appl Physiol 101: 1237-1242.

75. Hötting K, Röder B (2013) Beneficial effects of physical exercise on neuroplasticity and cognition. Neurosci Biobehav Rev 37: 2243-2257.

76. Kempermann G, Fabel K, Ehninger D, Babu H, Leal-Galicia P, et al. (2010) Why and how physical activity promotes experience-induced brain plasticity. Front Neurosci 4: 189.

77. Swanson RA, Sagar SM, Sharp FR (1989) Regional brain glycogen stores and metabolism during complete global ischaemia. Neurol Res 11: 24-28.

78. Wender R, Brown AM, Fern R, Swanson RA, Farrell K, et al. (2000) Astrocytic glycogen influences axon function and survival during glucose deprivation in central white matter. J Neurosci 20: 6804-6810.

79. Koizumi J (1974) Glycogen in the CNS. Progress in histochemistry and cytochemistry 6: 35.

80. Savchenko VL, McKanna JA, Nikonenko IR, Skibo GG (2000) Microglia and astrocytes in the adult rat brain: comparative immunocytochemical analysis demonstrates the efficacy of lipocortin 1 immunoreactivity. Neuroscience 96: 195-203.

81. Sloane JA, Hollander W, Rosene DL, Moss MB, Kemper T, et al. (2000) Astrocytic hypertrophy and altered GFAP degradation with age in subcortical white matter of the rhesus monkey. Brain Res 862: 1-10.

82. Rolfe DF, Brown GC (1997) Cellular energy utilization and molecular origin of standard metabolic rate in mammals. Physiol Rev 77: 731-758.

83. Ames A 3rd (2000) CNS energy metabolism as related to function. Brain Res Brain Res Rev 34: 42-68.

84. Chaudhuri A, Behan PO (2000) Fatigue and basal ganglia. J Neurol Sci 179: 34-42.

85. Chaudhuri A, Behan PO (2004) Fatigue in neurological disorders. Lancet 363: 978-988.

86. Newsholme EA, Blomstrand E, Ekblom B (1992) Physical and mental fatigue: metabolic mechanisms and importance of plasma amino acids. Br Med Bull 48: 477-495.

87. Smith EE, Jonides J (1999) Storage and executive processes in the frontal lobes. Science 283: 1657-1661.

88. Atherton M, Zhuang J, Bart WM, Hu X, He S (2003) A functional MRI study of high-level cognition. I. The game of chess. Brain Res Cogn Brain Res 16: 26-31.

89. Carter CS, van Veen V (2007) Anterior cingulate cortex and conflict detection: an update of theory and data. Cogn Affect Behav Neurosci 7: 367-379.

90. Caseras X, Mataix-Cols D, Rimes KA, Giampietro V, Brammer M, et al. (2008) The neural correlates of fatigue: an exploratory imaginal fatigue provocation study in chronic fatigue syndrome. Psychol Med 38: 941-951.

91. Tanaka M, Ishii A, Shigihara Y, Tajima S, Funakura M, et al. (2012) Impaired selective attention caused by mental fatigue. Journal of Neurological Sciences (Turkish) 29: 542-553.

92. Reingold EM, Charness N, Pomplun M, Stampe DM (2001) Visual span in expert chess players: evidence from eye movements. Psychol Sci 12: 48-55.

93. Reingold EM, Charness N, Schultetus RS, Stampe DM (2001) Perceptual automaticity in expert chess players: parallel encoding of chess relations. Psychon Bull Rev 8: 504-510.

94. Vasyukova EE (2012) The nature of chess expertise: knowledge or search? Psychology in Russia: State of the Art 5: 511-528.

95. Ericsson KA, Kintsch W (1995) Long-term working memory. Psychol Rev102: 211-245.

96. Gobet F, Simon HA (1996) Recall of random and distorted chess positions: implications for the theory of expertise. Mem Cognit 24: 493-503. 
97. Gobet F, Simon HA (1996) Templates in chess memory: A mechanism for recalling several boards. Cogn Psychol 31: 1-40.

98. Gobet F, Simon HA (2000) Five seconds or sixty? Presentation time in expert memory. Cognitive Science 24: 651-682.

99. Tikhomirov OK (1984) Psihologija myshlenija: Uchebnoe posobie [Psychology of thinking: Educational text-book]. Moscow: Moscow State University.

100. Holding D (1979) Echoic storage. Tutorial essays in psychology 2.

101. Charness N (1992) The impact of chess research on cognitive science. Psycholo res 54: 4-9.

102. Howard RW (2005) Are gender differences in high achievement disappearing? A test in one intellectual domain. J Biosoc Sci 37: 371-380.

103. van der Maas HL, Wagenmakers EJ (2005) A psychometric analysis of chess expertise. Am J Psychol 118: 29-60.

104. Charness N, Tuffiash M, Jastrzembski T (2004) Motivation, emotion and expert skill acquisition. Motivation, Emotion, and Cognition: Integrative Perspectives on Intellectual Functioning and Development, Lawrence Erlbaum Associates, Estados Unidos 299-320.

105. Goldin SE (1979) Recognition memory for chess positions: Some preliminary research. Am J Psychol 19-31.

106. De Groot AD, Gobet F, Jongman RW (1996) Perception and memory in chess: Studies in the heuristics of the professional eye. Van Gorcum \& Co.

107. Charness N, Reingold EM, Pomplun M, Stampe DM (2001) The perceptual aspect of skilled performance in chess: evidence from eye movements. Mem Cognit 29: 1146-1152.

108. Charness N (1981) Search in chess: Age and skill differences. J Exp Psychol Hum Percept Perform 7: 467-476.

109. Gobet F, Jansen PJ (2006) Training in chess: A scientific approach. Education and chess.

110. Simon HA, Gilmartin K (1973) A simulation of memory for chess positions. Cogn psychol 5: 29-46.

111. Gobet F, Clarkson G (2004) Chunks in expert memory: evidence for the magical number four ... or is it two? Memory 12: 732-747.

112. Gobet F, Simon HA (1998) Expert chess memory: revisiting the chunking hypothesis. Memory 6: 225-255.

113. Djakow IN, Petrowski NW, Rudik PA (1927) Psychologie des schachspiels. Psicología del Ajedrez".

114. Bilalic M, McLeod P (2006) How intellectual is chess? -- a reply to Howard. J Biosoc Sci 38: 419-421.

115. Grabner RH (2014) The role of intelligence for performance in the prototypical expertise domain of chess. Intelligence 45: 26-33.

116. Grabner RH, Stern E, Neubauer AC (2007) Individual differences in chess expertise: a psychometric investigation. Acta Psychol (Amst) 124: 398-420.

117. Viducic V, Šimunic S, Viducic L, Boras D (2009) Information Model For The Enhancement of Human Intelligence for the Period 2009-2020.
118. Bilalić M, Smallbone K, McLeod P, Gobet F (2009) Why are (the best) women so good at chess? Participation rates and gender differences in intellectual domains. Proc Biol Sci 276: 1161-1165.

119. Chabris CF, Glickman ME (2006) Sex differences in intellectual performance: analysis of a large cohort of competitive chess players. Psychol Sci 17: 1040-1046.

120. Irwing P, Lynn R (2005) Sex differences in means and variability on the progressive matrices in university students: a meta-analysis. Br J Psychol 96: 505-524.

121. Knapp M (2010) Are participation rates sufficient to explain gender differences in chess performance? Proc Biol Sci 277: 2269-2270.

122. Maass A, D'Ettole C, Cadinu M (2008) Checkmate? The role of gender stereotypes in the ultimate intellectual sport. Eur J Soc Psychol 38: 231-245.

123. Newell A, Shaw JC, Simon HA (1958) Chess-playing programs and the problem of complexity. IBM Journal of Research and Development 2: 320-335.

124. Tarnopolsky MA, Zawada C, Richmond LB, Carter S, Shearer J, et al. (2001) Gender differences in carbohydrate loading are related to energy intake. J Appl Physiol 91: 225-230.

125. Tarnopolsky LJ, MacDougall JD, Atkinson SA, Tarnopolsky MA, Sutton JR (1990) Gender differences in substrate for endurance exercise. J Appl Physiol (1985) 68: 302-308.

126. Tarnopolsky MA, Atkinson SA, Phillips SM, MacDougall JD (1995) Carbohydrate loading and metabolism during exercise in men and women. J Appl Physiol 78: 1360-1368.

127. James AP, Lorraine M, Cullen D, Goodman C, Dawson B, et al. (2001) Muscle glycogen supercompensation: absence of a gender-related difference. Eur J Appl Physiol 85: 533-538.

128. Kendrick ZV, Ellis GS (1991) Effect of estradiol on tissue glycogen metabolism and lipid availability in exercised male rats. J Appl Physiol (1985) 71: 1694-1699.

129. Nicklas BJ, Hackney AC, Sharp RL (1989) The menstrual cycle and exercise: performance, muscle glycogen, and substrate responses. Int J Sports Med 10: 264-269.

130. Ramamani A, Aruldhas MM, Govindarajulu P (1999) Differential response of rat skeletal muscle glycogen metabolism to testosterone and estradiol. Can J Physiol Pharmacol 77: 300-304.

131. Walker JL, Heigenhauser GJ, Hultman E, Spriet LL (2000) Dietary carbohydrate, muscle glycogen content, and endurance performance in well-trained women. J Appl Physiol (1985) 88: 2151-2158.

132. http://www.sportaccord.com/en/members/definition-of-sport/.

133. Bedau E (2014) Statement of the formerly counsellor of the German Chess Federation (DSB). 